\title{
The Effect of Personal Finance Education on The Financial Knowledge, Attitudes and Behaviour of University Students in Indonesia
}

\author{
Irni Johan ${ }^{1} \cdot$ Karen Rowlingson ${ }^{2}(-) \cdot$ Lindsey Appleyard $^{3}$
}

Accepted: 28 September 2020 / Published online: 18 November 2020

(c) The Author(s) 2020

\begin{abstract}
There is much debate about the impact of personal finance education on financial knowledge, attitudes and behaviour, particularly based on studies in the United Kingdom (UK) and United States of America (US). This paper makes a contribution to this debate, drawing on analysis of a survey of 521 undergraduate students at Bogor Agricultural University (IPB) in Indonesia in 2015. As part of that study, we measured the impact of a 14-week personal finance education course on financial knowledge, attitudes and behaviour. Our findings show that, when controlling for other factors, the personal finance course did, indeed, have a positive and statistically significant impact on financial knowledge. However, there was no statistically significant impact of the course on financial attitudes or behaviour. Our analysis also shows that family financial socialisation was an important driver of financial knowledge, attitudes and behaviour while other drivers of financial behaviour included income, work experience, year/field of study and discussing money with friends. We do not argue here that formal financial education is unimportant but that its role in changing attitudes and behaviour should be considered carefully if this is, indeed, its aim.
\end{abstract}

Keywords Financial education $\cdot$ Financial knowledge $\cdot$ Financial attitudes $\cdot$ Financial behaviour

\section{Introduction}

\section{Financial Capability and Education in an Increasingly Financialised World}

Financialisation and the rapid advances in information technology throughout the world have created a more complex

The research for this paper was carried out as part of doctoral studies by Irni Johan who was awarded her PhD in 2018 (see https://etheses.bham.ac.uk/id/eprint/8171/).

Electronic supplementary material The online version of this article (https://doi.org/10.1007/s10834-020-09721-9) contains supplementary material, which is available to authorized users.

Karen Rowlingson

K.Rowlingson@bham.ac.uk

1 Department of Family and Consumer Sciences, IPB University, Bogor, Indonesia

2 School of Social Policy, University of Birmingham, Edgbaston, Birmingham B15 2TT, UK

3 Centre for Business in Society, Coventry University, Coventry CV1 5FB, UK and dynamic financial sector, in terms of both products and systems (Marcolin and Abraham 2006). Individuals in low, middle, and high income countries are increasingly engaging with this financialised world and this has made money management more complex generally while also opening people up to new vulnerabilities such as risky financial transactions, misleading information, fraud and so on.

Younger generations today are in a particularly challenging situation. Jiang and Dunn (2013) revealed that young people had higher levels of debt, spent more money on credit cards, and tended to pay off bills relatively slowly compared to the previous generation at the same stage of life due to stagnating wages, low incomes, and paying off education fees. Furthermore, Jiang and Dunn (2013) point to easier access to credit and more permissive attitudes to debt as potentially contributing to young people's financial problems.

University or college students are a particularly interesting group to study in relation to financial capability issues. Starting to live independently, college students face new responsibilities to manage their finances, including budgeting, managing income and expenses, and paying bills. Moreover, in some countries, such as the United States (US), 
students also have access to student loans to cover their tuition fees (Dwyer et al. 2013). Elliot (1997), Holub (2002), and Boushey (2005) showed that the inability to plan-ahead may overwhelm students upon graduation, who may be overwhelmed by a debt burden, caused by their inability to manage student loans and credit cards. A study by Boushey (2005) revealed that high debt is accumulated when students enter college life, and at a higher rate for those on lower incomes.

Given the challenges facing young people in particular, there is clearly a growing need for support to help them understand and navigate our increasingly complex financial world. College students, in particular, might benefit from support to manage money while at college but also be more prepared for post-college life in terms of understanding financial products and services, and raising awareness of financial risks (Beal and Delpachitra 2003). Several studies suggest that support to increase financial knowledge, skills, attitudes, and behaviour (collectively referred to as 'financial capability'-see Kempson and Collard 2006; Atkinson et al. 2006) can be provided through education (for example, Shim et al. 2009; Sekita 2011; Klapper et al. 2013; Xiao and O'Neill 2016). In addition, a major review carried out on behalf of the U.S. Department of the Treasury (2015) on behalf of the U.S. Financial Literacy and Education Commission concluded that financial education programmes are effective in bringing about positive change on financial knowledge and expected financial behaviour. However, it was advised that more observations are needed in order to support a deeper understanding about suitable programmes (U.S. Department of the Treasury 2015). A study by Peng et al. (2007) showed that financial education delivered during college contributes positively and significantly to financial knowledge about investment patterns. However, contrary results were recorded by Mandell and Klein (2009) who did not find any difference in term of financial literacy and behaviour between those who took personal finance classes and those who had not. An experimental study by Cole et al. (2009) also found that financial education had no significant impact in increasing the use of bank/savings account. The study recorded that financial training only had a modest impact among those with low level of education, while it had no effect among the other groups/general population.

Financial capability can also be increased through nonformal financial socialisation agents, for example parents and peer groups (Gerrans and Heaney 2016; Fan and Chatterjee 2018). For example, Shim et al. (2010) argued that schools, workplaces and parents have a role in developing not only financial knowledge but also attitudes, and behaviour. The importance of financial socialisation by parents was reinforced by Johnson and Sherraden (2006) who encouraged parents to set aside time to discuss money and teach their children how to manage it wisely. As shown by
Jorgensen (2007), those who were subject to financial influence from their parents were more likely to achieve a better score of financial knowledge, attitudes, and behaviour.

It is clear that a number of studies have investigated the impact of financial education on various aspects of financial knowledge, attitudes and behaviour and some of these studies focus on U.S. college students. To our knowledge, there have been limited systematic studies of university students in other countries, including Indonesia.

\section{Financial Capability in Indonesia}

With a population of 261 million, Indonesia is the fourth most populous country in the world, after China, India and the US (The Office for National Statistics, Indonesia [Badan Pusat Statistik] [BPS] 2018). The demographic profile is young (average 28.6 years in 2016), with about 45 million aged 15-24 (BPS 2016). Moreover, Indonesia's economic performance shows impressive levels of growth (over 5\% per year) and the country is ranked as the world's tenth largest economy based on purchasing power parity and is thus also a G20 member (Setiawan 2015; The World Bank 2018). However, in terms of the financial sector, there appears to be a gap in the level of financial understanding and skills people have. The 2016 National Survey of Financial Literacy identified that only a third of respondents are classified as financially literate (OJK 2016).

Given the growth in GDP per capita for Indonesia, potential demand for financial products and services is projected to increase, meaning that the financial markets will develop further and become more complex e.g., with a growth in peer to peer lending (Financial Services Authority Indonesia (OJK) 2017). A student loan programme is also planned to be introduced by the government of Indonesia. ${ }^{1}$ Private financial institutions are also planning to expand in Indonesia e.g., in terms of consumer loans. Therefore, the need for appropriate knowledge and skills is increasingly important (Beal and Delpachitra 2003).

Our research aimed to measure the financial capability of Indonesian undergraduates at IPB University (Bogor Agricultural University/IPB). ${ }^{2}$ Financial capability is defined here as a combination of financial knowledge, attitudes, and behaviour as in Kempson et al. (2005), Atkinson et al. (2006), Johnson and Sherraden (2007). This paper focuses on the role of financial education in relation to financial capability.

\footnotetext{
${ }^{1}$ https://www.cnbcindonesia.com/tech/20190216190143-37-55930/ sejenis-kta-begini-sejarah-student-loan-di-indonesia.

2 This research is based on the $\mathrm{PhD}$ thesis of the first author and is available online at: https://etheses.bham.ac.uk/id/eprint/8171/
} 


\section{Theoretical Framework}

The theoretical framework used in this study drew on previous studies which have shown that financial education is one of a possible range of drivers of financial capability. In this framework, in addition to the personal finance course, the student's field of study was included as one of the observed variables. Several studies, such as Beal and Delpachitra (2003) and Fatoki and Oni (2014) revealed that business studies students have better financial knowledge, planning, and decision making, than those from non-business backgrounds, since they were exposed to the relevant topics more frequently.

Other possible drivers include level of income, financial socialisation, socio-economic status and work experience. For example, according to consumer socialisation theory, "individuals learn through their interactions with their environment, especially where they spend the most time and where they spent time in the early years of life" (Jorgensen 2007 p.47; see also Moschis and Churchill 1978; Gudmunson and Danes 2011; Fan and Chatterjee 2018).

Thus, financial habits can also be developed by watching how parents handle their financial matters, and how parents discussed money with their children. For example, those whose parents talked with them regularly about financial matters are considered to have higher levels of financial knowledge, positive financial attitudes, and in turn, behave in more financially responsible ways (Van Campen et al. 2010). Fan and Chatterjee (2018), also revealed that financial experience and socialisation, such as by family members, improved financial knowledge and skills. In addition, financial learning can also be gained from work experience. Working enables a person to obtain knowledge about managing money; by learning from experience, they can develop a sense of responsibility and increase their money-management expertise (e.g., Shim et al. 2009; Hilgert et al. 2003; Lowenstein et al. 2001; Sohn et al. 2012). Ajzen (1991) explains that, in general, individuals will have a positive attitude toward a certain behaviour when they believe that it will be associated with something positive, and vice versa.

Studies of financial capability have also noted that financial capability is linked to income and socioeconomic status (Worthington 2006; Mandell 2008; Loke 2017). For example, people who are less financially capable are more likely to have lower levels of education, to be young, female, single, unemployed, or on a lower income. In terms of income, several studies revealed (e.g., Cole et al. 2009; Xu and Zia 2012; Kempson et al. 2013) that those with a higher income are, unsurprisingly, more likely to be able to make ends meet which is one component of financial capability. This group also has more flexibility in allocating their resources and will therefore seek related information in order to achieve the optimum result. Thus, they are both aware and more familiar with financial issues. A noticeable variation could also be seen in terms of gender. It is reported that men tend to score higher than women in terms of financial capability (Chen and Volpe 1998; Manton et al. 2006; Danes and Haberman 2007; Peng et al. 2007; Hung et al. 2012). Danes and Hira (1987) showed that male students tended to have more knowledge about insurance and loans, while females were more knowledgeable about financial management in general. A study by Kempson et al. (2013) explained that women were better at managing money in the short term, but in other areas, such as choosing products and wealth accumulation, men showed higher performance. Meanwhile, contrasting results have been presented in several studies, such as Ramasawmy et al. (2013) and Ibrahim et al. (2009) and Shaari et al. (2013), did not find any difference between men and women in terms of the level of financial literacy.

In addition, year of study is also predicted to affect levels of financial capability due to greater financial experience. Danes and Hira (1987), Chen and Volpe (1998), and Shaari et al. (2013) showed that older students tended to have better scores when it came to knowledge about insurance and loans. The literature discussed shows varied results on the relationship between socio-demographic factors and levels of financial capability. This suggests that further research needs to be conducted. Therefore, in addition to examining the effects of formal financial education and financial capability, this study also examined the impact of (non-formal) financial socialisation and several socio-demographic variables, that is gender, year of study, field of study, and income. The framework of this study is illustrated in Fig. 1 below and our null hypotheses are as follows:

$\mathrm{HO}_{1}$ : There is no statistically significant difference on financial capability (financial knowledge, attitudes, and behaviour) between those who attended the personal finance course and those who had not attended the course. $\mathrm{HO}_{2}$ : Socio-demographic characteristics (gender, income, year/field of study, and work experience) have no impact on financial capability (financial knowledge, attitudes, and behaviour).

$\mathrm{HO}_{3}$ : Bogor Agricultural University (IPB)'s personal finance course has no impact on financial capability (financial knowledge, attitudes, and behaviour).

$\mathrm{HO}_{4}$ : Financial socialisation (from family and friends) has no impact on financial capability (financial knowledge, attitudes, and behaviour). 
Fig. 1 Drivers of Financial Capability

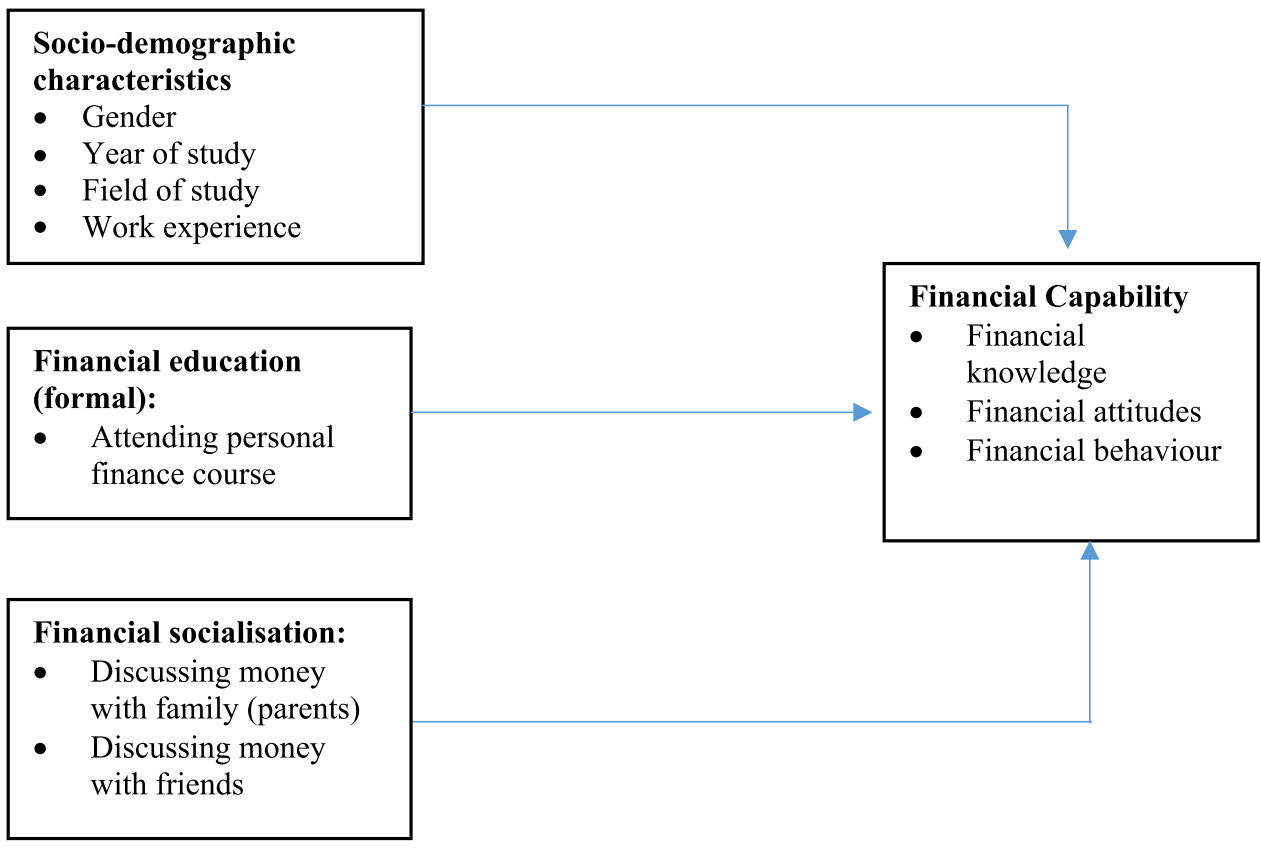

Financial education (formal): finance course

\section{Methods}

\section{Design of Study, Location, and Time}

This study adopted a cross-sectional design and was conducted in IPB (Bogor Agricultural University), Indonesia. Ranked as the third top university in Indonesia, ${ }^{3}$ the typical undergraduate programme at IPB takes four years to complete. In 2006, IPB began offering Personal Finance as both a compulsory module in the Department of Family and Consumer Sciences (IKK) and as an elective course for students from other departments. The course runs over 14 weeks with three hours of contact time each week, covering several topics ranging from the concept of financial management, time value of money, savings, credit/loan, tax, choosing products, risk management, insurance, investment, and retirement planning (see Table 1). There are very few universities in Indonesia that provide this type of course which is one of the main reasons why IPB was selected as the location of study. Fieldwork took place between May and September 2015.

\section{Population, Sampling and Response Rate}

The population of this study were all IPB undergraduate students, comprising 13,825 students. This study used stratified random sampling, with nine faculty and gender as the strata. Faculty refer to the main administrative groupings

\footnotetext{
3 https://ristekdikti.go.id/kabar/kemenristekdikti-umumkan-perin gkat-100-besar-perguruan-tinggi-indonesia-non-vokasi-tahun-2018/.
}

for the university, e.g., Faculty of Agriculture, Veterinary Medicine, Mathematics and Natural Science, Economics and Management and so on. According to the Slovin formula (Rivera and Rivera 2007), the minimum number of respondents needed was 510 students. In order to sample our respondents, a formal letter was sent to the Rector of IPB in order to obtain permission to conduct the survey and access a list of current students. From that list roughly 1000 participation invitations were sent by email and/or text message. Once someone agreed to participate an interview was then arranged. In cases where someone did not respond to the invitation, a weekly reminder email and/or text was sent. This was done three times. If there was still no response after three attempts, the student was replaced by another student who had also been selected randomly.

A total of 244 students declined to take part in the study, 98 did not respond to any contact, and 29 started the survey but did not complete it and so were not included in the final sample for analysis. The final sample size for analysis was 521 respondents. This is a response rate of $58 \%$ (521 out of 892 contacts). We also compared our achieved sample with the population for any particular biases and confirmed that there was no particular response bias (see Johan 2018) and hence no need for any sample weighting to correct for response bias.

The detailed characteristics of respondents are displayed in Table 2. First-year students were included in the survey but are not assigned to particular faculty, as they are completing a general foundation year.

For the data analysis purposes, faculty were then grouped into two categories, that is (1) Economic and Business Major students (from the Faculty of Economics and Management); 
Table 1 Syllabus of the personal finance course at Bogor Agricultural University course delivered over $3 \mathrm{~h}$ per week over 14 weeks

\begin{tabular}{|c|c|c|c|}
\hline Meeting No & Topic & Meeting No & Topic \\
\hline 1 & $\begin{array}{l}\text { The Concept of Personal Finance } \\
\text { The importance of personal finance } \\
\text { Decision making process } \\
\text { Financial goals }\end{array}$ & 8 & $\begin{array}{l}\text { Purchasing housing and vehicle } \\
\text { Consideration between buying in cash and taking a mortgage/ instalment } \\
\text { Estimating the cost }\end{array}$ \\
\hline 2 & $\begin{array}{l}\text { Financial Planning } \\
\text { Principle in financial planning } \\
\text { Financial life cycle } \\
\text { Financial ratio }\end{array}$ & 9 & $\begin{array}{l}\text { Managing risk and insurance } \\
\text { The concept of risk } \\
\text { Managing risk } \\
\text { Insurance policy } \\
\text { Home and vehicle insurance }\end{array}$ \\
\hline 3 & $\begin{array}{l}\text { Budgeting and Cash Flow } \\
\text { The importance of budgeting } \\
\text { Organising budget } \\
\text { Implementing budget } \\
\text { Budgeting evaluation }\end{array}$ & 10 & $\begin{array}{l}\text { Health insurance and life insurance } \\
\text { Determining the health risk } \\
\text { Health and life insurance } \\
\text { The cost and benefit of insurance }\end{array}$ \\
\hline 4 & $\begin{array}{l}\text { Managing income tax } \\
\text { Tax regulation } \\
\text { Types of compulsory tax } \\
\text { The purpose of paying taxes } \\
\text { The calculation of income tax }\end{array}$ & 11 & $\begin{array}{l}\text { Principle of investment and } \\
\text { investment in financial asset (Part 1) } \\
\text { The importance of investment } \\
\text { Investment philosophy } \\
\text { Introduction to the types of investment in financial assets (Certificate of } \\
\text { deposit and obligation) }\end{array}$ \\
\hline 5 & $\begin{array}{l}\text { Tools of money management } \\
\text { The definition of money management } \\
\text { Money management tool 1: checking } \\
\text { account } \\
\text { Money management tool 2: saving } \\
\text { account } \\
\text { Money management tool 3: instrument } \\
\text { of long-term investment (introduc- } \\
\text { tion) }\end{array}$ & 12 & $\begin{array}{l}\text { Investment in financial asset } \\
\text { (Part 2: stocks and mutual fund) } \\
\text { Stock: } \\
\text { General term } \\
\text { Buying and selling stock: Calculating the cost } \\
\text { Mutual Fund } \\
\text { General term } \\
\text { Types of mutual fund } \\
\text { Calculating the cost }\end{array}$ \\
\hline 6 & $\begin{array}{l}\text { Time value of money } \\
\text { Concept of time value of money } \\
\text { Simple interest } \\
\text { Compound interest }\end{array}$ & 13 & $\begin{array}{l}\text { Investment on real asset and strategy in managing the investment portfolio } \\
\text { Types of investment on real asset } \\
\text { Asset diversification }\end{array}$ \\
\hline 7 & $\begin{array}{l}\text { Loan and credit card } \\
\text { Consumer loan } \\
\text { Payment by credit (credit card) } \\
\text { Issues related to loan and credit } \\
\text { Calculation of financial cost }\end{array}$ & 14 & $\begin{array}{l}\text { Retirement plan } \\
\text { Source of income at pension time } \\
\text { Principle of pension fund } \\
\text { Calculating pension fund }\end{array}$ \\
\hline
\end{tabular}

Source: English translation of the syllabus of Personal Finance course, Bogor Agricultural University

and (2) Non-Economic Business Majors (other faculty). So, based on the field of study, we have $13 \%$ of the sample from Business-economics majors, and the rest were taking nonbusiness economic majors.

\section{Fieldwork Methods}

The survey was administered, face-to-face between May until September 2015. Given the large sample size for the face-to-face method, four paid-interviewers were involved in the data collection process. The interviewers were final year undergraduate students who had already had some training in research methods and they all had previous experience as an interviewer in other surveys. One of them was also chosen as the team leader in the field. All of the interviewers were trained for a minimum of $8 \mathrm{~h}$ before the data gathering process.

Before the main survey started, a pilot was carried out on other students who shared similar characteristics to the target sample. Besides testing for data quality control, such as question consistency and variation in respondents' answers, piloting was also done to find out the length of time needed for an interview. Based on the results of the pilot, the average interview duration was recorded as between 30 and $40 \mathrm{~min}$. Some minor changes were made to some questions, including instructions for the interviewer to skip and to filter questions, and the wording of some questions to improve the meaning following translation from English versions.

Interviews were held in the location agreed by the potential respondents, such as a campus cafeteria or canteen, 
Table 2 Characteristics of respondents

\begin{tabular}{|c|c|c|c|c|}
\hline No & Variable & & $n$ & Percent \\
\hline 1 & Faculty & $\begin{array}{l}\text { Agriculture } \\
\text { Fisheries and Marine Science } \\
\text { Animal Science } \\
\text { Forestry } \\
\text { Veterinary Medicine } \\
\text { Agricultural Technology } \\
\text { Mathematics and Natural Science } \\
\text { Human Ecology } \\
\text { Economics and Management }\end{array}$ & $\begin{array}{l}65 \\
62 \\
28 \\
57 \\
29 \\
64 \\
98 \\
52 \\
66\end{array}$ & $\begin{array}{l}12 \\
12 \\
5 \\
11 \\
6 \\
12 \\
19 \\
10 \\
13\end{array}$ \\
\hline 2 & Gender & $\begin{array}{l}\text { Male } \\
\text { Female }\end{array}$ & $\begin{array}{l}214 \\
307\end{array}$ & $\begin{array}{l}41 \\
59\end{array}$ \\
\hline 3 & Age & $\begin{array}{l}17 \\
18 \\
19 \\
20 \\
21 \\
22 \\
23 \\
24\end{array}$ & $\begin{array}{l}3 \\
53 \\
130 \\
116 \\
124 \\
83 \\
11 \\
1\end{array}$ & $\begin{array}{l}6 \\
10 \\
25 \\
22 \\
24 \\
16 \\
2 \\
2\end{array}$ \\
\hline 4 & Year of study (year enrolment) & $\begin{array}{l}\text { Year } 1 \\
\text { Year } 2 \\
\text { Year } 3 \\
\text { Year } 4\end{array}$ & $\begin{array}{l}131 \\
139 \\
80 \\
171\end{array}$ & $\begin{array}{l}25 \\
27 \\
15 \\
33\end{array}$ \\
\hline 5 & Work experience & $\begin{array}{l}\text { None } \\
\text { Less than one year } \\
\text { One to less than two years } \\
\text { Two years or more }\end{array}$ & $\begin{array}{l}266 \\
193 \\
48 \\
14\end{array}$ & $\begin{array}{l}51 \\
37 \\
9 \\
3\end{array}$ \\
\hline 6 & Completed personal finance course & $\begin{array}{l}\text { Had taken personal finance class } \\
\text { Had not taken personal finance class }\end{array}$ & $\begin{array}{l}50 \\
471\end{array}$ & $\begin{array}{l}9.2 \\
90.8\end{array}$ \\
\hline
\end{tabular}

campus hall, in the class after lectures, campus outside space, respondent's dormitory/home, and so on.

\section{Ethical Considerations}

The study received full ethical approval from the Humanities and Social Sciences Ethical Review Committee at the University of Birmingham prior to data collection. Informed consent was obtained from all individual participants included in the study. Data obtained in this study was maintained in accordance to the University's Code of Practice for Research. The data has been made openly available through the University of Essex (UK) Data Archive. ${ }^{4}$.

\section{Measures}

The questionnaire used in this study was based on the UK's Money Advice Service [MAS] (2013) questionnaire which, in turn, was based closely on the pioneering study by Kempson et al. (Kempson et al. 2005; Kempson and Collard 2006). This robust and well-tested questionnaire has been used in

\footnotetext{
4 https://beta.ukdataservice.ac.uk/datacatalogue/studies/study $?$ id $=853209$
}

many other studies, such as McKay (2011). In addition, however, we also used two questions from Lusardi and Mitchell's (2005) seminal study about compound interest (Q2) and risk diversification (Q4). The full questionnaire from the study (in English) is provided in the supplemental online material. We clearly had to translate the questionnaire into Indonesian and we also very slightly modified a few of the questions to make them more suitable for Indonesian undergraduate students given that these original questionnaires were developed for a general UK/US public survey. For example we used Indonesian currency rather than UK currency, we used an Indonesian version of a bank statement, added 'Eid' as an example of big event/national religious holiday, as the majority of Indonesian are Muslim. In this study, to ensure the validity, data in the questionnaire had also been tested using factor analysis (see the supplemental online material). To ensure the internal consistency, Cronbach's Alpha coefficient was applied to the scale questions relating to attitudes and behaviour (Pallant 2013), and the result was broadly acceptable $(0.736,0.610$ respectively). The detailed output of the reliability tests can be found in (Johan 2018, Appendix 17).

As a follow-up to Money Advice Service (2013), we conceptualised our key dependent variable, financial capability, 
as having three main dimensions: financial knowledge, attitudes, and behaviour.

In our study, we used financial knowledge to refer to what and how much is known about financial concepts. This was measured using questions focused on knowledge about managing money, inflation, interest rates, diversification, investment, credit cards, choosing financial products and pensions. There was also one question measuring whether respondents knew how to read a bank statement accurately (by asking them to do so and scoring them accordingly).

Moving on to financial attitudes, which refer to what a person feels and believes, and preferences in relation to personal finance matters, we included five sub-dimensions that focused on managing money, managing risk, planningahead, choosing products, and staying informed. In this study, 20 statements covering the five sub-dimesions of attitudes were measured using a Likert scale, ranging from 1 (strongly agree) to 5 (strongly disagree).

The third main dimension of financial capability was financial behaviour. This was defined as how people behave in relation to personal finance matters. To measure levels of behaviour, respondents were asked how frequently, if ever, they behaved in particular ways. A Likert scale was employed, on a five-point scale ranging from 1 (always) to 5 (never).

We also based our independent variables on the Money Advice Service (2013) study where appropriate (e.g., financial socialisation). Where some independent variables had not been used in previous studies (e.g., field of study) we developed these ourselves and then piloted them as mentioned above.

A copy of the full questionnaire, in English, can be found in the supplemental online material. The results presented here do not draw on every question, nevertheless the full questionnaire is shown for information.

\section{Data Analysis Approach}

The data obtained was processed using Microsoft Excel and SPSS. Data was inputted manually and then cleaned to check for any errors in data input. Initial descriptive analysis and inferential tests were conducted. The statistical inferential test examined the differences between groups and to determine the factors that influence financial capability.

Summary scores and indexes were then calculated separately for financial knowledge, attitude, and behaviour. For the knowledge questions, each of the correct answers was scored as " 1 " and the incorrect/others as " 0 ". As there were only two possibilities for the answer, that is 'correct' and 'incorrect', therefore in obtaining the score of financial knowledge, this was relatively straightforward as we added up the number of correct answers and transformed this into a scale from 0 to 100 .
For the attitude and behaviour questions, we first checked the direction of the agree/disagree scale for each item to ensure unidirectionality. Furthermore, in calculating the scores of attitudes and behaviour, a factor analysis was applied. Factor analysis gives a different weight to each question depending on how well it correlates with the factor. Factor analysis looks at the consistency of questions, or how much different questions seem to be measuring the same thing. A factor analysis of those questions is shown in the supplementary material file. The factor score is a linear combination (a weighted sum) of the observed variables, e.g.:

$\mathrm{F} 1=\mathrm{L} 1 \cdot \mathrm{X} 1+\mathrm{L} 2 \cdot \mathrm{X} 2+\mathrm{L} 3 \cdot \mathrm{X} 3+\ldots \mathrm{LN} \cdot \mathrm{XN}$

\section{Where:}

* $\mathrm{Fi}=$ factor, $\mathrm{Li}=$ loadings, and $\mathrm{Xi}=$ the $\mathrm{N}$ variables.

*The "weights" (Li) for the variables (Xi) are based on how much they "load" on the factor.

We then calculated the scores together from all items that made up the subscale or scale. The scores for the knowledge, attitude, and behaviour variables were then transformed so that they had the same range, i.e., 0-100. The overall scores of financial knowledge, attitudes, and behaviour were calculated as the arithmetic mean of the index. The general formula for the transformation index that was used in this study was as follows:

$\frac{\text { Total score achieved }- \text { Minimum score }}{\text { Maximum score - Minimum score }} \times 100$

Three models were then constructed to explore the impact of different factors on financial capability (financial knowledge, attitudes, and behaviour) with a multiple linear regression analysis carried out based on this model. The first model was designed to identify the driver for financial knowledge. The dependent variable is the composite score (index) of financial knowledge, while the independent variables are: gender (female and male), year enrolled (first year, and second year and above), whether they attended the personal finance course (yes or no), field of study (economicsbusiness and non-economics-business), work experience (yes or no), discussing money with family (yes or no), discussing money with a friend (yes or no), and income (ratio).

With the same independent variables as applied in the previous model, the second and third model was then constructed, to examine the drivers for financial attitudes and behaviour with the composite score (index) of financial attitudes and behaviour as the dependent variable in each model, respectively. The multiple linear regression model can be defined in the following equation:

$$
\begin{aligned}
& \mathrm{Y}_{1}=\alpha+\beta_{1} \mathrm{X}_{1}+\beta_{2} \mathrm{X}_{2}+\beta_{3} \mathrm{X}_{3}+\beta_{4} \mathrm{X}_{4}+\ldots \ldots . .+\beta_{8} \mathrm{X}_{8}+\varepsilon . \\
& \mathrm{Y}_{2}=\alpha+\beta_{1} \mathrm{X}_{1}+\beta_{2} \mathrm{X}_{2}+\beta_{3} \mathrm{X}_{3}+\beta_{4} \mathrm{X}_{4}+\ldots \ldots . .+\beta_{8} \mathrm{X}_{8}+\varepsilon .
\end{aligned}
$$


Table 3 Percentage of each group answering correctly on series of financial knowledge questions

\begin{tabular}{|c|c|c|c|c|c|c|}
\hline \multirow[t]{3}{*}{ No } & \multirow[t]{3}{*}{ Knowledge questions } & \multicolumn{2}{|c|}{ Percentage of correct answer } & \multicolumn{2}{|c|}{ Mann-Whitney test } & \multirow[t]{3}{*}{ Sig } \\
\hline & & \multirow{2}{*}{$\begin{array}{l}\text { Had taken } \\
\text { personal finance } \\
\text { course } \\
(\mathrm{N}=50)\end{array}$} & \multirow{2}{*}{$\begin{array}{l}\text { Had not taken } \\
\text { personal finance } \\
\text { course } \\
(\mathrm{N}=471)\end{array}$} & \multicolumn{2}{|l|}{ Mean Rank } & \\
\hline & & & & $\begin{array}{l}\text { Had taken } \\
\text { personal finance } \\
\text { course }\end{array}$ & $\begin{array}{l}\text { Had not taken } \\
\text { personal finance } \\
\text { course }\end{array}$ & \\
\hline 1 & $\begin{array}{l}\text { Impact of inflation on purchasing power of sav- } \\
\text { ings in future }\end{array}$ & 58 & 49 & 282.09 & 258.76 & 0.229 \\
\hline 2 & $\begin{array}{l}\text { Impact of (compound) interest on value of sav- } \\
\text { ings over } 5 \text { year period }\end{array}$ & 62 & 69 & 245.51 & 262.64 & 0.344 \\
\hline 3 & Discounted sales and percentages & 80 & 89 & 238.90 & 263.35 & $0.048^{*}$ \\
\hline 4 & $\begin{array}{l}\text { Difference in risk between buying single com- } \\
\text { pany's stock and stock mutual funds }\end{array}$ & 54 & 21 & 338.67 & 252.75 & $0.000^{*}$ \\
\hline 5 & Complex question on pension savings & 42 & 19 & 315.41 & 255.22 & $0.000^{*}$ \\
\hline 6 & Simple question on pension savings & 74 & 68 & 275.77 & 259.43 & 0.365 \\
\hline 7 & Credit card fraud & 62 & 49 & 292.01 & 257.71 & 0.077 \\
\hline 8 & Credit card ID theft & 66 & 45 & 310.43 & 255.75 & $0.005^{*}$ \\
\hline 9 & Ability to read a bank statement & 84 & 91 & 244.32 & 262.77 & 0.106 \\
\hline
\end{tabular}

$* p<0.05$

$\mathrm{Y}_{3}=\alpha+\beta_{1} \mathrm{X}_{1}+\beta_{2} \mathrm{X}_{2}+\beta_{3} \mathrm{X}_{3}+\beta_{4} \mathrm{X}_{4}+\ldots \ldots+\beta_{8} \mathrm{X}_{8}+\varepsilon$

$\mathrm{Y}_{1}=$ Financial knowledge (index).

$\mathrm{Y}_{2}=$ Financial attitudes (index).

$\mathrm{Y}_{3}=$ Financial behaviour (index).

$\mathrm{X}_{1}=$ Gender $(1=$ male, $0=$ female $)$.

$\mathrm{X}_{2}=$ Year enrolled $(1=$ year 2 and above; $0=$ year 1$)$.

$\mathrm{X}_{3}=$ Field of study category $(1=$ Economics-Business major; $0=$ non-Economics-Business major).

$\mathrm{X}_{4}=$ Personal finance category $(1=$ had taken the course; $0=$ had not taken the course).

$\mathrm{X}_{5}=$ Work experience $(1=$ had work experience; $0=$ no work experience).

$\mathrm{X}_{6}=$ Discussion of money with family $(1=\mathrm{yes}$; $0=$ never $)$.

$\mathrm{X}_{7}=$ Discussion of money with friends ( $1=$ yes; $0=$ never)

$\mathrm{X}_{8}=$ Income.

$\beta_{1-8}=$ Regression Coefficient.

$\alpha=$ Constant.

$\varepsilon=$ Error .

The analyses conducted in this study were as follows:

Descriptive analysis, to examine the general statistics of the data.

Mann-Whitney U Test, to examine the differences between two groups: that is between attendance of the personal finance class and each question on financial capability (financial knowledge, attitudes, and behaviour).

Independent sample T-test analysis, to examine the differences between two groups, that is between attendance of personal finance class and financial capability score (financial knowledge, attitudes, and behaviour/ the index score).

Factor score, to obtain the loading factor of financial attitudes and behaviour for the purpose of developing an index score of financial attitudes and behaviour (the scale type answer).

Multiple linear regression analysis, to determine the factors that influence financial capability (financial knowledge, attitudes, and behaviour). Before starting the multiple regression test, various tests were employed, including tests of normality; autocorrelation, multicollinearity; and homescedasticity (Pallant 2013, p.156-157), and the Open University (n.d)). All tests performed well.

\section{Results}

The analysis began by comparing the financial knowledge, attitudes, and behaviour (financial capability) of those who took part in the financial education course with those who did not. We then present the results of a multiple linear regression analysis to consider the impact of the course on the different components of financial capability when taking into account other potential factors.

\section{Financial Knowledge}

Table 3 shows the percentage of people correctly answering a number of financial knowledge questions, comparing those who had attended the personal finance course and those who 
Table 4 Independent samples T-Test between financial knowledge and attendance on the personal finance course

\begin{tabular}{|c|c|c|c|c|c|}
\hline \multirow[t]{2}{*}{ Area } & \multicolumn{2}{|c|}{$\begin{array}{l}\text { Had not taken per- } \\
\text { sonal finance course } \\
\text { (Score } 0-100)\end{array}$} & \multicolumn{2}{|c|}{$\begin{array}{l}\text { Had taken personal } \\
\text { finance course (Score } \\
0-100)\end{array}$} & \multirow[t]{2}{*}{$\begin{array}{l}\text { T-test } \\
\text { (p) }\end{array}$} \\
\hline & Mean & $\begin{array}{l}\text { Standard } \\
\text { deviation }\end{array}$ & Mean & $\begin{array}{l}\text { Standard } \\
\text { deviation }\end{array}$ & \\
\hline $\begin{array}{l}\text { Financial } \\
\text { knowledge }\end{array}$ & 56 & 19 & 65 & 21 & $0.001 *$ \\
\hline
\end{tabular}

$* p<0.05$

had not. The most difficult question for respondents was a complex question about pension savings (Question 5). Only one in five students (19\%) who had not attended the financial education course answered this question correctly. Students who had attended the course were more than twice as likely to answer correctly ( $42 \%$ ) but this was still less than half the group. The difference between the two groups was statistically significant. Furthermore, all questions were multiple choice so some people may have guessed the answers correctly without really knowing the answer. There was a similar level of difficulty in relation to a question about single company stocks and stock mutual funds (Question 4). It is likely that undergraduate students have had much less direct engagement with pensions and stock funds, hence the lack of understanding of these issues (though with a statistically significantly higher level of knowledge among those who had taken the course-54\% versus $21 \%$ ). Knowledge of credit card ID theft was also much higher among those who had attended the course than those who had not $(66 \%$ versus $45 \%$ on Questions 8), again statistically significantly so.

If we look at knowledge of issues that perhaps fall more within the experience of the students, we saw statistically significantly higher levels of knowledge about discounted sales (Question 3) but in this case the higher level of knowledge was among students who had not attended the coursethough the difference was relatively small ( $89 \%$ versus $80 \%$ for those who attended the course).

A summary score for financial knowledge was then calculated as explained above. We also employed the Independent samples $t$-test to examine the difference between the group based on the general score of financial knowledge (index score). As we can see in Table 4, the result of independent samples $t$-test showed significant differences in financial knowledge amongst those who had attended the personal finance course and those who had not, where the $p$-value was found to be less than 0.05 .

This study therefore revealed that respondents who had attended the personal finance course had a statistically significantly higher score on financial knowledge overall than those who did not.

\section{Financial Attitudes}

As discussed earlier, financial attitudes were broken down into five sub-dimensions: managing money, managing risk, planning ahead, choosing products, and staying up-to-date (Table 5). Within each sub-dimension, respondents were asked the extent to which they agreed or disagreed with various statements. Unlike the questions on financial knowledge, there is not necessarily a "right" answer in terms of attitudes although there are some cultural norms which favour saving over spending and borrowing for example. We make no normative judgement here about which attitudes are "right" or "wrong" but merely report on any differences between those who took the personal finance course and those who did not. Regarding managing money, over $80 \%$ of all students agreed that they were very organised when it comes to managing money and there was no statistically significant difference between the two groups on this question. The same was true of the question about whether people saw themselves as savers or spenders. There were no statistically significant differences on these questions. However, there was a slight difference between those who attended the course and those who did not when it came to preferring to buy things on credit rather than wait and save up. Here we saw a statistically significantly higher proportion of those who attended the course disagreeing with this statement. Overall, there were very few differences between the two groups, although perhaps more of an aversion to credit use among those who had attended the course.

In relation to risk management, those who had attended the course showed a higher level of trust in the financial services industry, though levels of trust were generally low across both groups. A statistically significant difference between groups was found on Q5, Q6, and Q8 (Table 5). But even so, students were more likely to say that life insurance was not necessary and were also more likely to say that they chose not to take out home insurance.

Both groups exhibited highly positive views around planning ahead with no statistically significant group difference on this aspect of financial attitudes. Meanwhile, on the final two sub-dimensions of financial attitudes (choosing products and staying up-to-date), there was relatively little difference between our two groups in terms of overall levels of agreement. Those who attended the course were more likely to strongly agree with the statements on choosing products than those who had not but there was no statistically significant difference, overall, between our two groups on any of these questions.

There were clearly a large number of questions on attitudes and so to summarise our findings we calculated a mean score (Table 6). The highest mean score-that is, highest level of agreement was in choosing products, while the attitudes toward risk and insurance was the lowest (with a statistically 
Table 5 Financial attitudes by attendance on the personal finance course

Q Statements

Taken personal Percentage of answer Mann-Whitney test finance course $(\%)$

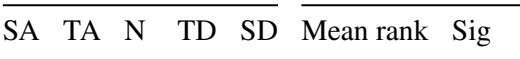

Managing money

1 I am very organised when it comes to managing my money day to day

2 I am more of a saver than a spender

3 I prefer to buy things on credit rather than wait and save up

4 Prefer cut-back than spending on a credit card couldn't repay

Managing risk

5 I can trust the information provided by insurance companies about policies

6 I am confident that insurance policies would pay out if I ever needed them to No

Yes

7 I accept the risks and choose not to pay for home content insurance

8 Paying for life insurance is not necessary

9 Credit cards are safe and risk free

10 Not paying full billing of credit card as long have made the minimum payment

Planning ahead

11 I always make sure I have money saved for a rainy day

12 I always begin saving well in advance for a big event (Christmas, Eid, etc.)

13 Pension funds are the best way to save for retirement

14 I prefer to live for today rather than plan for tomorrow

15 Having rainy day saving is important

16 Planning how to pay for the old care is important

Choosing products

17 Comparing prices before buying is important)

18 Searching information before deciding to buy is important

19 It is important to read carefully the agreement/contract before signing it

Staying up-to-date

20 Keep up-to- date with financial matters is important
No

Yes

$\begin{array}{llllll}30 & 50 & 12 & 8 & 0 & 260.17 \\ 32 & 50 & 10 & 6 & 2 & 268.86 \\ 18 & 53 & 21 & 8 & 0 & 260.23 \\ 20 & 52 & 24 & 4 & 0 & 268.24 \\ 3 & 18 & 15 & 51 & 13 & 257.50 \\ 4 & 10 & 8 & 62 & 16 & 293.93 \\ 23 & 59 & 10 & 7 & 1 & 256.22 \\ 38 & 54 & 2 & 4 & 2 & 306.01\end{array}$

0.673

No

Yes

No

Yes

No

Yes

$\begin{array}{llllll}38 & 54 & 2 & 4 & 2 & 306.01\end{array}$

$\begin{array}{llllll}2 & 26 & 38 & 31 & 3 & 256.01\end{array}$

$0.014^{*}$

$\begin{array}{llllll}8 & 38 & 30 & 24 & 0 & 307.99\end{array}$

$\begin{array}{llllll}2 & 38 & 40 & 19 & 1 & 254.16\end{array}$

$\begin{array}{llllll}8 & 56 & 26 & 10 & 0 & 325.39\end{array}$

$\begin{array}{llllll}1 & 28 & 38 & 30 & 3 & 257.62\end{array}$

$\begin{array}{llllll}6 & 38 & 26 & 26 & 4 & 292.86\end{array}$

Yes

No

Yes

No

Yes

No

Yes

$\begin{array}{llllll}5 & 54 & 22 & 16 & 3 & 254.94\end{array}$

$\begin{array}{llllll}22 & 50 & 18 & 8 & 2 & 318.12\end{array}$

$\begin{array}{llllll}10 & 51 & 19 & 17 & 3 & 257.39\end{array}$

$\begin{array}{llllll}20 & 48 & 20 & 12 & 0 & 294.98\end{array}$

$\begin{array}{llllll}6 & 45 & 30 & 18 & 1 & 257.24\end{array}$

$\begin{array}{llllll}16 & 48 & 18 & 18 & 0 & 296.42\end{array}$

No

Yes

No

Yes

No

Yes

No

Yes

No

Yes

No

Yes

$\begin{array}{llllll}41 & 52 & 4 & 3 & 0 & 263.40\end{array}$

0.208

$\begin{array}{llllll}30 & 64 & 2 & 2 & 2 & 238.39\end{array}$

$\begin{array}{llllll}26 & 56 & 12 & 6 & 0 & 259.04\end{array}$

$\begin{array}{llllll}32 & 54 & 8 & 6 & 0 & 279.49\end{array}$

$\begin{array}{llllll}16 & 43 & 21 & 19 & 1 & 258.14\end{array}$

$\begin{array}{llllll}20 & 50 & 14 & 14 & 2 & 287.90\end{array}$

$\begin{array}{llllll}3 & 14 & 19 & 53 & 11 & 258.79\end{array}$

$\begin{array}{llllll}4 & 12 & 10 & 60 & 14 & 281.86\end{array}$

$\begin{array}{llllll}45 & 49 & 5 & 1 & 0 & 261.47\end{array}$

$\begin{array}{llllll}44 & 50 & 2 & 4 & 0 & 256.58\end{array}$

$\begin{array}{llllll}43 & 50 & 6 & 1 & 0 & 259.86\end{array}$

$\begin{array}{llllll}45 & 50 & 1 & 2 & 2 & 271.76\end{array}$

$\begin{array}{lllllll}\text { No } & 36 & 53 & 8 & 2 & 1 & 259.28\end{array}$

0.375

Yes

$\begin{array}{llllll}44 & 44 & 6 & 4 & 2 & 277.17\end{array}$

No

$\begin{array}{llllll}34 & 57 & 7 & 2 & 0 & 258.15\end{array}$

Yes

$\begin{array}{llllll}46 & 46 & 2 & 6 & 0 & 287.87\end{array}$

No

$\begin{array}{llllll}49 & 45 & 4 & 2 & 0 & 258.77\end{array}$

Yes

$\begin{array}{llllll}60 & 32 & 4 & 4 & 0 & 281.98\end{array}$

No

$\begin{array}{llllll}24 & 50 & 24 & 2 & 0 & 260.36\end{array}$

0.748

$S A$ Strongly Agree, $T A$ Tend to Agree, $N$ Neither Agree or Disagree, $T D$ Tend to Disagree, $S D$ Strongly Disagree $* p<0.05$ 
Table 6 Independent samples $T$-test between financial attitudes and attendance on the personal finance course

\begin{tabular}{|c|c|c|c|c|c|}
\hline \multirow[t]{2}{*}{ Area } & \multicolumn{2}{|c|}{$\begin{array}{l}\text { Had not taken } \\
\text { personal finance } \\
\text { course (Score } \\
0-100)\end{array}$} & \multicolumn{2}{|c|}{$\begin{array}{l}\text { Had taken } \\
\text { personal finance } \\
\text { course (Score } \\
0-100)\end{array}$} & \multirow[t]{2}{*}{$\begin{array}{l}\text { T-test } \\
\text { (p) }\end{array}$} \\
\hline & Mean & $\begin{array}{l}\text { Standard } \\
\text { deviation }\end{array}$ & Mean & $\begin{array}{l}\text { Standard } \\
\text { deviation }\end{array}$ & \\
\hline $\begin{array}{l}\text { Financial attitudes } \\
\text { overall }\end{array}$ & 77 & 10 & 80 & 15 & 0.095 \\
\hline \multicolumn{6}{|l|}{ Different components: } \\
\hline Managing money & 72 & 15 & 75 & 17 & 0.128 \\
\hline Risk and insurance & 57 & 14 & 65 & 16 & $0.001 *$ \\
\hline Planning ahead & 79 & 11 & 80 & 15 & 0.888 \\
\hline Choosing products & 82 & 14 & 84 & 18 & 0.428 \\
\hline Staying informed & 74 & 19 & 75 & 18 & 0.651 \\
\hline
\end{tabular}

$* p<0.05$

significant difference between our two groups on this subdimension of attitudes). Familiarity with the issue is a plausible explanation here. We also found that those who had taken the personal finance course were more likely to record higher scores in all domains, as shown by the mean scores. However, the independent $t$-test analysis showed that there was no statistically significant difference in overall attitudes between those who had attended the personal finance course and those who had not (at the $95 \%$ level of confidence).

\section{Financial Behaviour}

As discussed earlier, financial behaviour was measured here by asking respondents how often they behaved in certain ways. Table 7 shows that students who had attended the personal finance course were statistically significantly more likely than those who had not to say they had a weekly or monthly budget that they follow (Q8). They were also more likely to say they begin saving well before a big event (Q6) and regularly set money aside for savings (Q9).

At the same time, however, they were statistically significantly less likely to have run out of money by the end of the month (Q4). While they said they kept track of their money and tried to save, they seemed to struggle to manage on their income more than other students.

These findings confirmed the complex nature of financial capability. People may be stronger on some dimensions of financial capability than others. In addition, there does seem to be a possible contradiction between regularly setting money aside for savings while at the same time spending more money than they had. The findings may demonstrate the existence of social desirability bias on reported behaviour as some participants may have felt that they should be saving and so reported that they were saving even if they saved very little, if at all.

Once again, given the large number of questions measuring behaviour, we summarised the data in Table 8 using the same mean score method as for financial attitudes. Table 8 shows the differences between those who had taken the personal finance course and those who had not, to reveal that those who had attended the course showed statistically different scores with respect to their financial behaviour, with a higher score recorded by those who had taken the course.

\section{Financial Knowledge, Attitudes, and Behaviour: The Effect of Financial Education}

The analysis so far suggests that financial education may have some impact on financial capability but there is a chance that those who took the personal finance course were systematically different from those who did not, and these differences may explain the variation in financial capability. The next step for our analysis was therefore to carry out a multiple linear regression analysis, building on our theoretical framework (see Fig. 1). This revealed that the key determinants of financial knowledge were: field of study; attendance in the personal finance course; work experience and financial socialisation from family. Indeed, the results showed that field of study and attendance in the personal finance course were the strongest factors that influenced financial knowledge (Table 9).

The following model explains the determinants of financial knowledge:

$$
\begin{aligned}
\text { Financial knowledge }= & 40.120+8.670 \text { field of study } \\
& +7.060 \text { personal finance course } \\
& +5.150 \text { work experience } \\
& +6.695 \text { family socialisation }
\end{aligned}
$$

Meanwhile, gender, field of study, work experience, and financial socialisation from family, had an impact on financial attitudes. Female students, Economics and Business majors, those who had work experience, and those who discussed money with family, had higher chances to have more desirable financial attitudes. In line with the analysis shown in Table 6, analysis with regression showed that there was no statistically significant effect in financial attitudes between those who had and had not attended the course, once other factors were controlled for (Table 9). The model for financial attitudes can be summarised by the following equation:

$$
\begin{aligned}
\text { Financial attitudes }= & 69.681-2.096 \text { gender } \\
& +3.512 \text { field of study } \\
& +2.645 \text { work experience } \\
& +5.971 \text { discussing money with family }
\end{aligned}
$$


Table 7 Detailed responses of financial behaviour based on the personal finance course

\begin{tabular}{|c|c|c|c|c|c|c|c|c|c|}
\hline \multirow[t]{2}{*}{ Q } & \multirow[t]{2}{*}{ Statements } & \multirow{2}{*}{$\begin{array}{l}\text { Taken Personal } \\
\text { finance course }\end{array}$} & \multicolumn{5}{|c|}{ Percentage of answer (\%) } & \multicolumn{2}{|c|}{ Mann-Whitney test } \\
\hline & & & Always & $\begin{array}{l}\text { Most of } \\
\text { the time }\end{array}$ & $\begin{array}{l}\text { Some } \\
\text { times }\end{array}$ & Hardly ever & Never & Mean Rank & Sig \\
\hline \multirow[t]{2}{*}{1} & \multirow{2}{*}{$\begin{array}{l}\text { Checking the balance/ask for mini statements } \\
\text { before withdrawing cash }\end{array}$} & No & 18 & 22 & 28 & 24 & 8 & 255.98 & 0.016 \\
\hline & & Yes & 32 & 20 & 30 & 16 & 2 & 308.30 & \\
\hline \multirow[t]{2}{*}{2} & \multirow{2}{*}{$\begin{array}{l}\text { In the past } 12 \text { months, had money left over at the } \\
\text { end of the month }\end{array}$} & No & 16 & 21 & 30 & 22 & 11 & 263.34 & 0.263 \\
\hline & & Yes & 6 & 26 & 30 & 24 & 14 & 238.96 & \\
\hline \multirow[t]{2}{*}{3} & \multirow[t]{2}{*}{ keeping track of income and expenditure } & No & 3 & 8 & 4 & 1 & 84 & 259.38 & 0.238 \\
\hline & & Yes & 6 & 10 & 6 & 0 & 78 & 276.27 & \\
\hline \multirow[t]{2}{*}{4} & \multirow{2}{*}{$\begin{array}{l}\text { In the last } 12 \text { months, run out of money before the } \\
\text { end of the month }\end{array}$} & No & 1 & 14 & 34 & 25 & 26 & 267.17 & $0.003 *$ \\
\hline & & Yes & 6 & 24 & 36 & 22 & 12 & 202.88 & \\
\hline \multirow[t]{2}{*}{5} & \multirow[t]{2}{*}{ I avoid spending more money than I have } & No & 33 & 36 & 22 & 7 & 2 & 261.38 & 0.853 \\
\hline & & Yes & 28 & 44 & 20 & 4 & 4 & 257.44 & \\
\hline \multirow[t]{2}{*}{6} & \multirow{2}{*}{$\begin{array}{l}\text { I begin saving well in advance for big events, such } \\
\text { as Christmas, Eid }\end{array}$} & No & 11 & 30 & 34 & 19 & 6 & 255.12 & $0.005^{*}$ \\
\hline & & Yes & 18 & 46 & 22 & 10 & 4 & 316.35 & \\
\hline \multirow[t]{2}{*}{7} & \multirow[t]{2}{*}{ I save money for a rainy day } & No & 3 & 9 & 50 & 29 & 9 & 258.38 & 0.186 \\
\hline & & Yes & 4 & 12 & 54 & 24 & 6 & 285.70 & \\
\hline \multirow[t]{2}{*}{8} & \multirow[t]{2}{*}{ I have a weekly (or monthly) budget that I follow } & No & 6 & 15 & 31 & 30 & 18 & 255.29 & $0.006^{*}$ \\
\hline & & Yes & 14 & 18 & 38 & 22 & 8 & 314.83 & \\
\hline \multirow[t]{2}{*}{9} & \multirow[t]{2}{*}{ I regularly set aside money each month for savings } & No & 3 & 10 & 42 & 37 & 8 & 300.86 & $0.035^{*}$ \\
\hline & & Yes & 4 & 18 & 44 & 32 & 2 & 256.77 & \\
\hline \multirow[t]{2}{*}{10} & \multirow{2}{*}{$\begin{array}{l}\text { Collect information about different products/ser- } \\
\text { vices before buying }\end{array}$} & No & 40 & 37 & 18 & 5 & 0 & 259.71 & 0.946 \\
\hline & & Yes & 38 & 42 & 16 & 2 & 2 & 261.14 & \\
\hline \multirow[t]{2}{*}{11} & \multirow[t]{2}{*}{ I make a complaint for unsuitable product } & No & 12 & 27 & 34 & 20 & 7 & 258.41 & 0.894 \\
\hline & & Yes & 6 & 34 & 32 & 26 & 2 & 261.27 & \\
\hline \multirow[t]{2}{*}{12} & \multirow[t]{2}{*}{ I read the contract carefully before signing it } & No & 58 & 27 & 10 & 4 & 1 & 260.69 & 0.871 \\
\hline & & Yes & 60 & 24 & 10 & 4 & 2 & 263.92 & \\
\hline 13 & I read to increase my financial knowledge & No & 6 & 14 & 34 & 34 & 12 & 257.94 & 0.137 \\
\hline & & Yes & 10 & 18 & 38 & 20 & 14 & 289.84 & \\
\hline 14 & Monitor financial issues & No & 8 & 31 & 15 & 19 & 27 & 260.57 & 0.838 \\
\hline & & Yes & 6 & 32 & 14 & 30 & 18 & 265.01 & \\
\hline
\end{tabular}

Christmas and Eid are major religious festivals celebrated $* p<0.05$

Table 8 Independent samples $T$-test between financial behaviour and attendance on the personal finance course

\begin{tabular}{|c|c|c|c|c|c|}
\hline \multirow[t]{2}{*}{ Area } & \multicolumn{2}{|c|}{$\begin{array}{l}\text { Had not taken per- } \\
\text { sonal finance course } \\
\text { (Score } 0-100)\end{array}$} & \multicolumn{2}{|c|}{$\begin{array}{l}\text { Had taken personal } \\
\text { finance course (Score } \\
0-100)\end{array}$} & \multirow[t]{2}{*}{$\begin{array}{l}\text { T-test } \\
\text { (p) }\end{array}$} \\
\hline & Mean & $\begin{array}{l}\text { Standard } \\
\text { deviation }\end{array}$ & Mean & $\begin{array}{l}\text { Standard } \\
\text { deviation }\end{array}$ & \\
\hline $\begin{array}{l}\text { Financial } \\
\text { behaviour }\end{array}$ & 49 & 16 & 55 & 15 & $0.018 *$ \\
\hline
\end{tabular}

Moreover, in terms of financial behaviour, the regression analysis showed that the drivers of financial behaviour were financial socialisation from family and friends, work experience, field of study, income, and year of study $(p<0.05)$. Furthermore, attendance of the personal finance course was only significant at the level of confidence $90 \%(p<0.1)$ (Table 9). The regression model of financial behaviour can be expressed by the following equation:

$$
\begin{aligned}
\text { Financial behaviour }= & 28.975+3.296 \text { year enrolled } \\
& +4.815 \text { field of study }+4.863 \text { work experience } \\
& +5.898 \text { discussing money with family } \\
& +5.157 \text { discussing money with friend } \\
& +4.309 \text { income }
\end{aligned}
$$




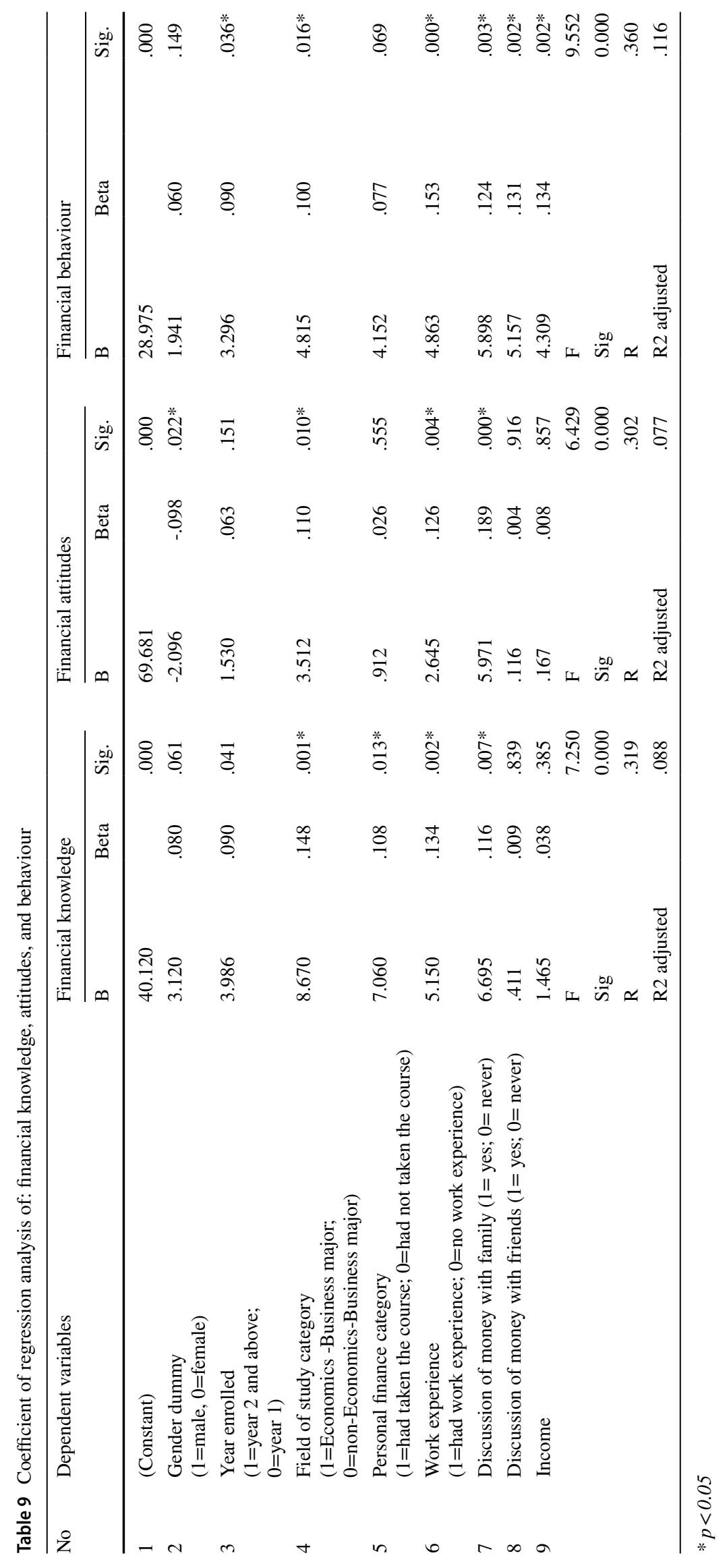




\section{Summary and Discussion of Findings}

\section{Main Findings}

Our findings suggest that, if we do not control for other factors, those who attend the personal finance course have statistically significantly higher levels of financial knowledge overall than those who do not. They also report different types of financial behaviour. But the attitudes of these two groups, on a range of financial issues, do not differ from each other.

Any differences between our two groups could, however, be accounted for by potential variations in the composition of the two groups. Perhaps those who attended the course, for example, were more likely to be students in economics or business courses and so had a higher level of knowledge before taking the course. And perhaps those who took the course have a higher level of income and so are better able to manage their money (thus reporting different financial behaviours). Our regression analysis therefore draws on existing debates and theory about the factors that influence financial capability. Basically, after controlling for these factors, attendance in the personal finance course still had an impact on financial knowledge but not on financial attitudes or financial behaviour.

In some ways, this is not a surprising finding given that the aim of an education course is to increase knowledge. However, it is often assumed, or even hoped, that personal financial education will change attitudes and behaviours to increase people's ability to manage money. Indeed, this seems to be the implicit if not explicit purpose of many financial education courses.

While the research suggests that attendance in a personal finance education course is associated with higher levels of knowledge, other factors have an impact, including the year of enrollment, field of study, work experience, and discussion of money with the family. In terms of financial attitudes, field of study, work experience and discussion of money with the family are the key, factors here. A number of factors are also associated with different financial behaviours namely field of study, year of enrollment, work experience, discussion of money with family, discussion of money with friends and income.

Three factors are associated with different levels of financial knowledge, attitudes, and behaviour, including work experience discussion of money with family, and field of study. About four in ten respondents had work experience such as a part-time job or running a small business. In this study, work experience is one of the strong determinant factors, perhaps because workers are learning from the experience of managing money. Indeed, Lowenstein et al. (2001) stresses the link between personal experience and knowledge/behaviour change. But another important explanation could be that those who have a job have higher incomes and so are better able to manage their money (and so score more highly in terms of financial behaviour) (see also Xiao and O’Neill 2016).

It is also interesting to note that families play an important role in developing student's financial knowledge, attitudes, and especially behaviours. This is in line with the theory of consumer socialisation discussed earlier (Jorgensen 2007). This finding also supports the studies by Gerrans and Heaney (2016) and Clarke et al. (2005) that found that family discussion of financial goals, value, and money matters improve financial capability. Thus informal learning appears to be even more important perhaps than formal education in relation to financial capability.

The importance of field of study suggests that some people may be more interested in personal finance issues (hence choosing business-economics degree courses) and perhaps also learn about the issues in those courses more than those studying veterinary science for example.

Year of enrollment is significant in relation to financial knowledge and behaviour. This reinforces the point that experience generally is important in increasing knowledge and changing behaviour. People learn through experience in managing incomes, spending, and saving themselves, as much, perhaps, as through a formal education course.

Income is statistically significant when related to financial behaviour. Income appears to affect behaviour as it enables people to save or spend. But it does not appear related to knowledge or attitudes. This finding confirms that the broader economic context of income levels and living standards are also important here. If people are living on poverty level incomes they will not have enough money to manage it effectively and, for example, save. Financial education therefore needs to be underpinned by policies to support people on precarious or low incomes and those experiencing poverty (McKay et al. 2019; Rowlingson et al. 2016).

Finally, it is interesting that the role of peers became relevant only in relation to behaviour but not knowledge or attitudes. Gender is not related to financial knowledge, or behaviour once controlling for other factors.

\section{Limitations}

It is important to bear in mind a number of issues with the design of this study which affect the interpretation of our findings. First, survey data is subject to social desirability bias whereby respondents may wish to give what they consider to be socially desirable answers and this may particularly affect answers to questions on financial attitudes and behaviour for which there are fairly strong cultural norms. Second, even where respondents are not affected by social desirability bias, their answers to behaviour questions may represent some degree of wish-fulfilment rather than actual 
behaviour. In other words, their actual behaviour may not correlate with their reported behaviour. This limitation is the same for all the major international studies that use surveys to measure financial capability. Studies that measure behaviour more directly are much less common due to the difficulties involved in implementing them though further studies of this type would be welcome.

In relation to measuring the impact of the personal finance education course, a cross-section design cannot definitively provide evidence of causal relationships. A longitudinal, randomised control trial would be the most appropriate method as it can help deal with selection effects and further studies of this type would be welcome.

And, finally in terms of limitations, this is a study seeking to measure the impact of a personal finance education course in one university, in a particular country, at a single point in time (2015) and thus the findings may not be generalized to other samples of college students.

\section{Conclusion}

This is the first major study, to our knowledge, to measure financial capability among Indonesian undergraduates, using a highly rigorous face-to-face fieldwork method involving a large sample size, high response rate and a detailed, welltested questionnaire. The opportunity to compare those who have attended an in-depth personal finance course with those who have not is also a strength of the study and hence the focus of this paper.

The key contribution from our research is to demonstrate that a personal financial education course for undergraduate university students may increase financial knowledge but is less likely to affect financial attitudes or behaviour. Other factors, such as informal learning through socialisation and experience appear to also increase financial knowledge but also affect financial attitudes and behaviour. Income is also important in relation to financial behaviour. So if the goal of policy makers is to promote financial education to change financial behaviour, it is important to provide employment opportunities to change levels of income, and to learn about finances informally and through experience as well as through formal financial education programmes.

Of course, not all young people have the opportunity to engage with financial socialisation (Verhelst and Saskatcehwan 2016), work experience, or financial products or services in positive ways. Therefore, consistent with Borden et al. (2008), for those who lack such experience, financial education can be an important a way to enhance financial knowledge and increase an individual's capacity to manage their finances. And, indeed, it may be the case that this education eventually helps people manage money better when they do see their incomes increase and/or have the chance to work.

This is a very important conclusion, particularly for Indonesia, with its predominately young population at a time of increasing financialisation. It means that we cannot necessarily expect formal financial education to change financial attitudes and behaviour directly but that it can increase financial knowledge. A question for further research then could be, "what type of financial education should be implemented so it can enhance financial capability more effectively? (Mountain et al. 2020).

Given our findings about the importance of experience, our research supports the argument of Johnson and Sherraden (2006) that well-designed financial education programmes should give individuals the chance to attain practical experience, because learning from experience and practice is important for knowledge retention (MAS 2013). As also suggested by Sohn et al. (2012), learning is more effective if the students are actively involved, as this enables them to develop a deeper understanding of the content , and develop longer lasting attitudes and behaviour through experience (Sohn et al. 2012; Johnson and Sheraden 2007; Joo and Grable 2004). Our findings certainly support this and we therefore recommend that personal finance courses are designed to include as much experiential learning as possible.

Furthermore, we recommend that policy needs to recognise the importance of family socialisation in promoting effective financial capability as an antecedent of financial wellbeing. We suggest that schools, universities, and employers could be supported to conduct ongoing financial education programmes to increase financial capability through discussions about financial issues within the home. This would mean that financial education is not just a one-off event but an ongoing process through the lifecourse as people's needs and financial products change. In this way, adults can keep up to date with the increasingly complex financial system, whilst children and young people can become better prepared to leave home or attend university. Promoting financial education is critical to ensure that citizens understand the nature of financial services and how to make better financial decisions to improve financial wellbeing, alongside raising incomes.

Acknowledgements The authors would like to thank LPDP (Indonesian Endowment Fund for Education) for sponsoring the $\mathrm{PhD}$, and the CHASM (Centre on Household Assets and Savings Management), the University of Birmingham, UK, for covering some of the fieldwork costs. We would also like to thank the editors of the journal and the reviewers for their valuable and constructive feedback.

Author contributions This paper is based on the $\mathrm{PhD}$ research by Irni Johan. Karen Rowlingson and Lindsey Appleyard were her supervisors. All authors contributed to the study conception, design and material preparation. Data collection and initial analysis was performed by Irni 
Johan. The first draft of the manuscript was written by Irni Johan and all authors commented on, and directly edited, previous versions of the manuscript. All authors read and approved the final manuscript.

Funding As mentioned above, LPDP sponsored the $\mathrm{PhD}$ research and CHASM contributed to some of the fieldwork costs for this study.

Open Access This article is licensed under a Creative Commons Attribution 4.0 International License, which permits use, sharing, adaptation, distribution and reproduction in any medium or format, as long as you give appropriate credit to the original author(s) and the source, provide a link to the Creative Commons licence, and indicate if changes were made. The images or other third party material in this article are included in the article's Creative Commons licence, unless indicated otherwise in a credit line to the material. If material is not included in the article's Creative Commons licence and your intended use is not permitted by statutory regulation or exceeds the permitted use, you will need to obtain permission directly from the copyright holder. To view a copy of this licence, visit http://creativecommons.org/licenses/by/4.0/.

\section{References}

Ajzen, I. (1991). The theory of planned behavior. Organizational Behavior and Human Decision Processes, 50(1), 179-211. https ://doi.org/10.1016/0749-5978(91)90020-T.

Atkinson, A., McKay, S., Kempson, E., \& Collard, S. (2006). Levels of Financial Capability in the UK: Results of a Baseline Survey. London: Financial Services Authority (FSA).

BPS (Badan Pusat Statistik/The Office for National Statistics Indonesia) (2016). Statistik Indonesia: Statistical Yearbook of Indonesia 2016. Edited by Sub-directorate of Statistical Compilation and Publication. Jakarta , Indonesia: Badan Pusat Statistik/ BPS-Statistic.

BPS (Badan Pusat Statistik/The Office for National Statistics Indonesia). (2018). Statistik Indonesia: Statistical Yearbook of Indonesia 2018. Jakarta: Badan Pusat Statistik/ BPS-Statistic Indonesia.

Beal, D. J., \& Delpachitra, S. B. (2003). Financial literacy among Australian University students. Economic Papers, 22(1), 65-78.

Borden, L. M., Lee, S.-A., Serido, J., \& Collins, D. (2008). Changing college students' financial knowledge, attitudes, and behavior through seminar participation. Journal of Family and Economic Issues, 29(1), 23-40. https://doi.org/10.1007/s10834-007-9087-2.

Boushey, H. (2005). Student Debt: Bigger and Bigger. CEPR Briefing Paper. Washington, D.C: Center for Economic and Policy Research.

Van Campen, K. S., Serido, J., \& Shim, S. (2010). A roadmap for young adults' financial well-being. Frances McClelland Institute for Children, Youth, and Families Research Link, 2(3), 2-3.

Chen, H., \& Volpe, R. P. (1998). An analysis of personal financial literacy among college students. Financial Services Review, 7(2), 107-128.

Clarke, M. C., Heaton, M. B., Israelsen, C. L., \& Eggett, D. L. (2005). The acquisition of family financial roles and responsibilities. Family and Consumer Sciences Research Journal, 33(4), 321-340.

Cole, S., Sampson, T., \& Zia, B. (2009). Financial literacy, financial decisions, and the demand for financial services : Evidence from India and Indonesia. Harvard Business School Working Paper No. 09-117.

Danes, S. M., \& Haberman, H. R. (2007). Teen financial knowledge, self-efficacy, and behavior: A gendered view. Financial Counseling and Planning, 18(2), 48-60.

Danes, S. M., \& Hira, T. K. (1987). Money management knowledge of college students. Journal of Student Financial Aid, 17(1), 3-16.
Dwyer, R. E., Hodson, R., \& McLoud, L. (2013). Gender, debt, and dropping out of college. Gend Soc, 27(1), 30-55.

Elliot, J. (1997). Young and in debt: A focus on prevention. Credit World, 85(4), 35-36.

Fan, L., \& Chatterjee, S. (2018). Financial socialization, financial education, and student loan debt. Journal of Family and Economic Issues, 40(4), 74-85. https://doi.org/10.1007/s10834-018-9589-0.

Fatoki, O., \& Oni, O. (2014). Financial literacy studies in South Africa: Current literature and research opportunities. Mediterranean Journal of Social Sciences, 5(20), 409-414.

Gerrans, P., \& Heaney, R. (2016). The impact of undergraduate personal finance education on individual financial literacy, attitudes and intentions. Accounting and Finance, 59(1), 177-217. https:// doi.org/10.1111/acfi.12247.

Gudmunson, C. G., \& Danes, S. M. (2011). Family financial socialization: Theory and critical review. Journal of Family and Economic Issues, 32(4), 644-667. https://doi.org/10.1007/s 1083 4-011-9275-y.

Hilgert, M. A., Hogarth, J. M., \& Beverly, S. G. (2003). Household financial management: The connection between knowledge and behavior. Federal Reserve Bulletin, 106, 309-322.

Holub, T. (2002). Credit Card Usage and Debt among College and University Students. Washington, DC: ERIC Digest ERIC Publications EDO-HE-2002-O.

Hung, A., Yoong, J., \& Brown, E., (2012). Empowering women through financial awareness and education. OECD Working Papers on Finance, Insurance and Private Pensions. https://doi. org/10.1787/5k $9 \mathrm{~d} 5 \mathrm{v} 6 \mathrm{kh} 56 \mathrm{~g}$-en.

Ibrahim, D., Harun, R., \& Isa, Z. M. (2009). A study on financial literacy of malaysian degree students. Cross-Cultural Communication, 5(4), 51-59.

Jiang, S. S., \& Dunn, L. F. (2013). New evidence on credit card borrowing and repayment patterns. Economic Inquiry, 51(1), 394 407. https://doi.org/10.1111/j.1465-7295.2012.00456.x.

Johan, I. R. (2018). Financial capability among university students in Indonesia. $\mathrm{PhD}$ thesis, University of Birmingham. https://ethes es.bham.ac.uk/id/eprint/8171/.

Johnson, E., \& Sherraden, M. S. (2006). From Financial Literacy to Financial Capability among Youth Working Paper 06-11. St.Louis,MO:Washington University: Center for Social Development.

Johnson, E., \& Sherraden, M. S. (2007). From financial literacy to financial capability among youth. The Journal of Sociology and Social Welfare, 34(3), 119-145.

Joo, S., \& Grable, J. E. (2004). An exploratory framework of the determinants of financial satisfaction. Journal of Family and Economic Issues, 25(1), 25-50.

Jorgensen, B. L. (2007). Financial Literacy of College Students: Parental and Peer Influences Master Thesis. Virgina: Virginia Polytechnic Institute and State University.

Kempson, E., \& Collard, S. (2006). Financial Capability baseline survey: questionnaire. London: Financial Services Authority, The Personal Finance Research Centre, University of Bristol in collaboration with Jenny Turtle and Alan Worley at BMRB Limited and the FSA.

Kempson, E., Collard, S., \& Moore, N. (2005). Measuring financial capability: An exploratory study. London: Financial Services Authority.

Kempson, E., Perotti, V., \& Scott, K. (2013). Measuring Financial Capability: A New Instrument and Results from Low-and MiddleIncome Countries. London: Financial Services Authority.

Klapper, L., Lusardi, A., \& Panos, G. A. (2013). Financial literacy and its consequences: Evidence from Russia during the financial crisis. Journal of Banking and Finance, 37(10), 3904-3923. 
Loke, Y. (2017). The influence of socio-demographic and financial knowledge factors on financial management. International Journal of Business and Society, 18(1), 33-50.

Lowenstein, G. F., Weber, E. U., Hsee, C. K., \& Welch, N. (2001). Risk as Feelings. Psychological Bulletin, 127(2), 267-286.

Lusardi, A., \& Mitchell, O.S. (2005). Financial Literacy and Planning: Implications for Retirement Wellbeing joint with Olivia Mitchell. In: A. Lusardi and O Mitchell (eds), "Financial Literacy. Implications for Retirement Security and the Financial Marketplace," (PP. 17-39). Oxford: Oxford University Press.

McKay, S., Rowlingson, K., \& Overton, L. (2019). Financial inclusion annual monitoring briefing paper. Birmingham: University of Birmingham.

Mandell, L. (2008). The financial literacy of young American adults: Result of the 2008 National jump\$tart coalition survey of high school seniors and college students, jump\$tart coalition for personal financial literacy. Available at: https://www.jumpstart.org/ assets/files/2008SurveyBook.pdf. Accessed 20 September 2017.

Mandell, L., \& Klein, L. S. (2009). The impact of financial literacy education on subsequent financial behavior. Journal of Financial Counseling and Planning, 20(1), 15-24.

Manton, E. J., English, D. E., Avard, S., \& Walker, J. (2006). What college freshmen admit to not knowing about personal finance. Journal of College Teaching \& Learning, 3(1), 43-54.

Marcolin, S., \& Abraham, A. (2006). Financial Literacy Research: Current Literature and Future Opportunities. In Basu, P., O’Neill, G., and Travaglione, A. (eds.), Proceedings of the 3rd International Conference on Contemporary Business, Leura NSW (pp. 21-22). Australia: Faculty of Commerce, Charles Stuart University.

McKay, S. (2011) 'Understanding Financial Capability in Canada Analysis of the Canadian Financial Capability Survey'. Research paper prepared for the Task Forceon Financial Literacy.

Money Advice Service (MAS). (2013). The Financial Capability of the UK. London: Money Advice Service.

Moschis, G. P., \& Churchill, G. A., Jr. (1978). Consumer socialization: A theoretical and empirical analysis. Journal of Marketing Research, 15(4), 599-609.

Mountain, P., Kim, N., Serido, J., \& Shim, S. (2020). Does type of financial learning matter for young adults' objective financial knowledge and financial behaviors? A longitudinal and mediation analysis. Journal of Family and Economic Issues. https://doi. org/10.1007/s10834-020-09689-6.

OJK. (2016). Indonesian Financial Services Sector Master Plan 2015-2019, Financial Services Authority (OJK). Jakarta, Indonesia: OJK.

OJK (Otoritas Jasa Keuangan/Indonesia Financial Services Authority). (2017). Statistik Perbankan Syariah/Sharia Banking Statistic 2017. Jakarta: Otoritas Jasa Keuangan.

Pallant, J. (2013). SPSS survival manual: a step by step guide to data analysis using IBM SPSS (5th ed.). Berkshire: Open University Press.

Peng, T. C., Bartholomae, M. S., \& Fox, J. J. (2007). The impact of personal finance education delivered in High School and College courses. J Fam Econ, Iss, 28, 265-284.

Ramasawmy D., Thapermall S., Dowlut S. A., \& Ramen M. (2013) 'A Study of the Level of Awareness of Financial Literacy among Management Undergraduates', Proceedings of 3rd Asia-Pacific Business Research Conference. Kuala Lumpur, Malaysia.
Rivera, M., Jr., \& Rivera, R. V. (2007). Practical Guide to Thesis and Dissertation Writing. Quezon City, Philippines: Katha Publishing Inc.

Rowlingson, K., Appleyard, L., \& Gardner, J. (2016). Payday lending in the UK: The Regul(Aris)Ation of a necessary evil? Journal of Social Policy, 45(3), 527-543.

Sekita, S. (2011). Financial literacy and retirement planning in Japan. Journal of Pension Economics and Finance, 10(4), 637-656.

Setiawan, S. (2015). Pendekatan Purchasing Power Parity dalam PDB dan Kualitas Kesejahteraan Indonesia. In C. Tjahjaprijadi (Ed.), Dinamika Kebijakan Fiskal Paradigma Baru dalam Mendorong Kebijakan Ekonomi yang Berkelanjutan (pp. 27-44). PT Nagakusuma Media Kreatif: Jakarta.

Shaari, N. A., Hasan, N. A., Mohamed, R. K. M. H., \& Sabri, M. A. J. M. (2013). Financial literacy: A study among the University students. Interdisciplinary Journal of Contemporary Research in Business, 5(2), 279-299.

Shim, S., Serido, J., \& Xiao, J.J. (2009). Arizona Pathways to Life Success for University Students: Cultivating Positive Financial Attitudes and Behaviors for Healthy Adulthood. Tucson, Arizona: National Endowment for Financial Education (NEFE), John \& Doris Norton School of Family \& Consumer Sciences, College of Agriculture and Life Sciences, Take Charge America Institute for Consumer Financial Education and Research, The University of Arizona.

Shim, S., Barber, B., Card, N. A., Xiao, J. J., \& Serido, J. (2010). Financial socialization of first-year college students: The roles of parents, work, and education. Journal of Youth and Adolescence, 39(12), 1457-1470.

Sohn, S., So-Hyun, G., \& J.E., Lee, S. \& Kim, M., (2012). Adolescents' financial literacy: The role of financial socialization agents, financial experiences, and money attitudes in shaping financial literacy among South Korean Youth. Journal of Adolescence, 35(4), 969-980. https://doi.org/10.1016/j.adolescence.2012.02.002.

The Open University (n.d). Assumptions of Multiple Regression. Available at: https://www.open.ac.uk/socialsciences/spsstutorial/files/ tutorials/assumptions.pdf. Accessed 8 Jan 2018.

The World Bank. (2018). Indonesia Economic Quarterly: Towards inclusive growth. Report. March 2018. The World Bank.

U.S. Department of Treasury. (2015). Opportunities to Improve the Financial Capability and Financial Well-being of Postsecondary Students. Washington, USA: The Financial Literacy and Education Commission.

Verhelst, B.D., \& Saskatchewan, R. (2016). The Systemic Nature of Personal Debt: A Critical Realist Approach to Analyses and Solutions. Master Thesis. University of Regina, Regina, Canada.

Worthington, A. C. (2006). Predicting financial literacy in Australia. Financial Services Review, 15(1), 59-79.

Xiao, J. J., \& O'Neill, B. (2016). Consumer financial education and financial capability. International Journal of Consumer Studies, 40(6), 712-7221.

Xu, L., \& Zia, B. (2012). Financial literacy around the world: An overview of the evidence with practical suggestions for the way forward. Policy Research Working Paper. https://doi. org/10.3102/00346543067001043.

Publisher's Note Springer Nature remains neutral with regard to jurisdictional claims in published maps and institutional affiliations. 